\title{
Analisis Stabilitas Bendung Kamijoro
}

\author{
Gentur Pinandito $^{\text {a*}}$, Puji Harsanto ${ }^{\mathrm{b}}$ \\ ${ }^{a}$ Tim Supervisi Bendungan, PT. Virama Karya, Semarang \\ ${ }^{b}$ Program Studi Teknik Sipil, Fakultas Teknik, Universitas Muhammadiyah Yogyakarta
}

\section{Riwayat Artikel}

Diserahkan

1 Desember 2020

Direvisi

4 Januari 2021

Diterima

1 Februari 2021

*Penulis korespondensi gpinandito@gmail.com

\section{Abstrak}

Bendung Kamijoro direncanakan untuk suplesi air di Bendung Pijenan yang mengairi daerah irigasi seluas 2.370 ha, yang terdiri atas daerah irigasi Jigutan seluas 296 ha dan Kebonongan seluas 2.074 ha. Selain dapat menyalurkan irigasi secara optimal, bendung juga harus memenuhi persyaratan stabilitas. Penelitian ini bertujuan untuk mengetahui nilai faktor aman Bendung Kamijoro terhadap gelincir, guling, maupun pipping yang mana merupakan persyaratan utama dalam menentukan apakah bendung dapat dikatakan stabil atau tidak. Pada kajian ini, pengecekan stabilitas terhadap terhadap pipping dilakukan dengan menggunakan Metode Lane, untuk pengecekan geser maupun guling dilakukan dengan menganalisis gaya-gaya yang bekerja pada bendung. Selain itu, dilakukan pula analisis reaksi pondasi akibat gaya-gaya vertikal yang bekerja pada bendung. Hasil dari nilai fakor aman bendung terhadap gelincir adalah sebesar 0,14 dan guling adalah sebesar 2,3 dengan persyaratan nilai faktor aman minimum sebesar 0,2 dan 1,69. Nilai angka aman rembesan terhadap pipping adalah 134,13 untuk kondisi muka air banjir dan 7,93 untuk kondisi muka air normal, dengan persyaratan angka aman minimum untuk rembesan Lane pada jenis pasir kasar adalah sebesar 5,0. Maka, dapat disimpulkan bahwa Bendung Kamijoro aman terhadap geser, guling maupun pipping.

Kata-kata kunci: stabilitas bendung, metode jaringan aliran, rembesan, erosi bawah tanah

\section{PENDAHULUAN}

Bendung adalah bangunan air yang dibangun secara melintang pada suatu sungai dan dibuat untuk meninggikan muka air sehingga air sungai dapat disadap dan dialirkan secara gravitasi ke jaringan irigasi (Direktorat Jenderal Sumber Daya Air, 2013). Permasalahan-permasalahan pada bendung sering sekali terjadi sehingga menghambat kinerja suatu bendung dan berakibat suplai air ke jaringan irigasi menjadi kurang optimal. Kerusakan-kerusakan dini yang terjadi pada bendung merupakan suatu permasalahan utama yang terjadi karena ketidakstabilan bendung dalam menghadapi gaya-gaya yang bekerja pada bendung itu sendiri. Beberapa kerusakan- kerusakan yang terjadi adalah erosi pada tanah di bawah bendung, rusaknya lantai rendah, pecahnya badan bendung, gerusan pasir/lumpur dan kerusakan lainnya akibat ketidakstabilan bendung (Prastumi dkk., 2011). Dengan adanya permasalahan tersebut, maka perlu dilakukan kontrol stabilitas terhadap Bendung Kamijoro, sehingga Bendung Kamijoro dapat memenuhi persyaratanpersyaratan stabilitas yang telah ditentukan, yaitu gelincir, guling dan erosi bawah tanah atau pipping (Prasasti dkk.,
2013). Pada perhitungan stabilitas bendung, kolam olak diasumsikan dalam keadaan kering apabila dilakukan perhitungan pada saat debit normal, yaitu dimana tinggi muka air hanya mencapai elevasi puncak mercu (Syofyan \& Frizaldi, 2017). Selain itu, pada saat debit banjir untuk tinggi muka air banjir maksimum dianjurkan tidak lebih dari 4,5 meter (Mangroe dkk., 2013).

Tinjauan dari segi eksentrisitas, daya dukung tanah, serta rembesan perlu dilakukan karena bendung haruslah aman terhadap penurunan tanah akibat beban struktur bangunan dan piping akibat rembesan yang terjadi (Firnanda dkk., 2011). Rembesan atau seepage terjadi karena perbedaan tinggi muka air pada bendung, sehingga aliran pada bagian hulu merembes masuk ke dalam tanah di sekitar bendung, maka berakibat timbulnya aliran air di dalam tanah dan memicu terjadinya pipping (Sukirman, 2014). Aliran air tanah juga dapat memicu terjadinya kegagalan struktur akibat gaya tekan ke atas air (uplift) (Asl dkk., 2015). Gaya uplift menyebabkan perlawanan gaya antara pondasi dengan tubuh bendung, sehingga memberikan tekanan maupun tegangan pada tubuh bendung yang dapat menurunkan nilai dari faktor aman geser maupun guling (Shahrbanozadeh dkk., 2015). 
Pipping sangat bergantung terhadap kekuatan tahanan aliran air yang ada di dalam tanah. Tahanan aliran air bergantung kepada jenis tanah, ukuran butiran, bentuk butiran, rapat massa, serta bentuk geometri rongga pori. Tanah berbutir halus memiliki rembesan yang kecil dan daya rembes yang besar, hal ini dikarenakan tanah tersebut memiliki rapat massa yang tinggi sehingga mengakibatkan aliran rembesan yang masuk kedalam tanah akan sangat sedikit dan kecepatan alirannya akan besar, sehingga tahanan terhadap aliran air akan semakin kuat untuk jenis tanah tersebut. Sebaliknya dengan tanah berbutir kasar, karena rongga pori yang besar maka tanah ini akan mudah untuk ditembus air, sehinnga jenis tanah ini akan lebih rawan terhadap terjadinya pipping (Sompie \& Puntororing, 2014). Selain itu, pemasangan sheet pile yang lebih dalam pada bendung juga mampu untuk mengurangi terjadinya pipping (Aziz \& Abdallah, 2017). Selain pipping, rembesan juga memicu terjadinya penyumbatan (clogging), yang terjadi karena air yang meresap memindahkan partikel-partikel yang tersimpan pada bagian pori tanah. Sehingga, efektifitas pori tanah dan konduktifitas hidrolik tanah berkurang, maka terjadilah penyumbatan. Maka, kemungkinan terjadi pipping berkurang karena seepage dapat tereduksi secara perlahan (Sroka dkk., 2014).

Dalam studi ini dilakukan dengan menentukam nilai dari faktor aman stabilitas pada Bendung Kamijoro terhadap gelincir, guling dan pipping. Stabilitas terhadap gelincir dan guling dianalisis dengan metode perhitungan gaya-gaya dan momen yang bekerja pada bendung, sementara itu stabilitas terhadap pipping dianalisis menggunakan Metode Angka Rembesan Lane. Sehingga dari hasil nilai faktor aman tersebut dapat diketahui bahwa Bendung Kamijoro dapat dikatakan stabil atau tidak stabil.

\section{METODE PENELITIAN}

\subsection{Lokasi Penelitian}

Penelitian tugas akhir ini dilakukan pada Bendung Kamijoro yang terletak pada aliran Sungai Progo pada Daerah Irigasi Kamijoro di Desa Sendangsari, Kecamatan Pajangan, Kabupaten Bantul. Sungai Progo ini memiliki panjang sungai utama 138 km, sisi barat dibatasi Gunung Sumbing, sisi timur Gunung Merbabu dan Merapi (Gambar 1). Kali Progo ini memiliki luasan DAS sebesar $2380 \mathrm{~km}^{2}$. Jenis tanah pada lokasi tersebut adalah pasir, karena berkaitan dengan kondisi endapan Sungai Progo di lokasi sekitar Intake Kamijoro.

\subsection{Analisis Gaya Berat Bangunan}

Gaya berat bangunan dilakukan perhitungan dengan arah vertikal kebawah yang garis kerjanya melewati titik berat konstruksi, dan untuk kemudahan dalam perhitungannya maka tubuh bendung dibagi menjadi beberapa pias (Sabihi dkk., 2017). Perhitungan gaya berat bangunan dapat dilakukan deng mengalikan volume tubuh bendung pada pias tinjauan dengan rapat massa bahan bangunan (beton). Pembagian pias tubuh bendung Kamijoro ditunjukkan pada Lampiran Gambar A.1. Momen berat dihitungdengan mengalikan gaya berat tubuh bendung dengan lengan momen.

\subsection{Analisis Gaya Gempa}

Gaya gempa dilakukan perhitungan dengan arah horizontal dan garis kerjanya melewati titik berat konstruksi. Perhitungan gaya gempa dilakukan dengan

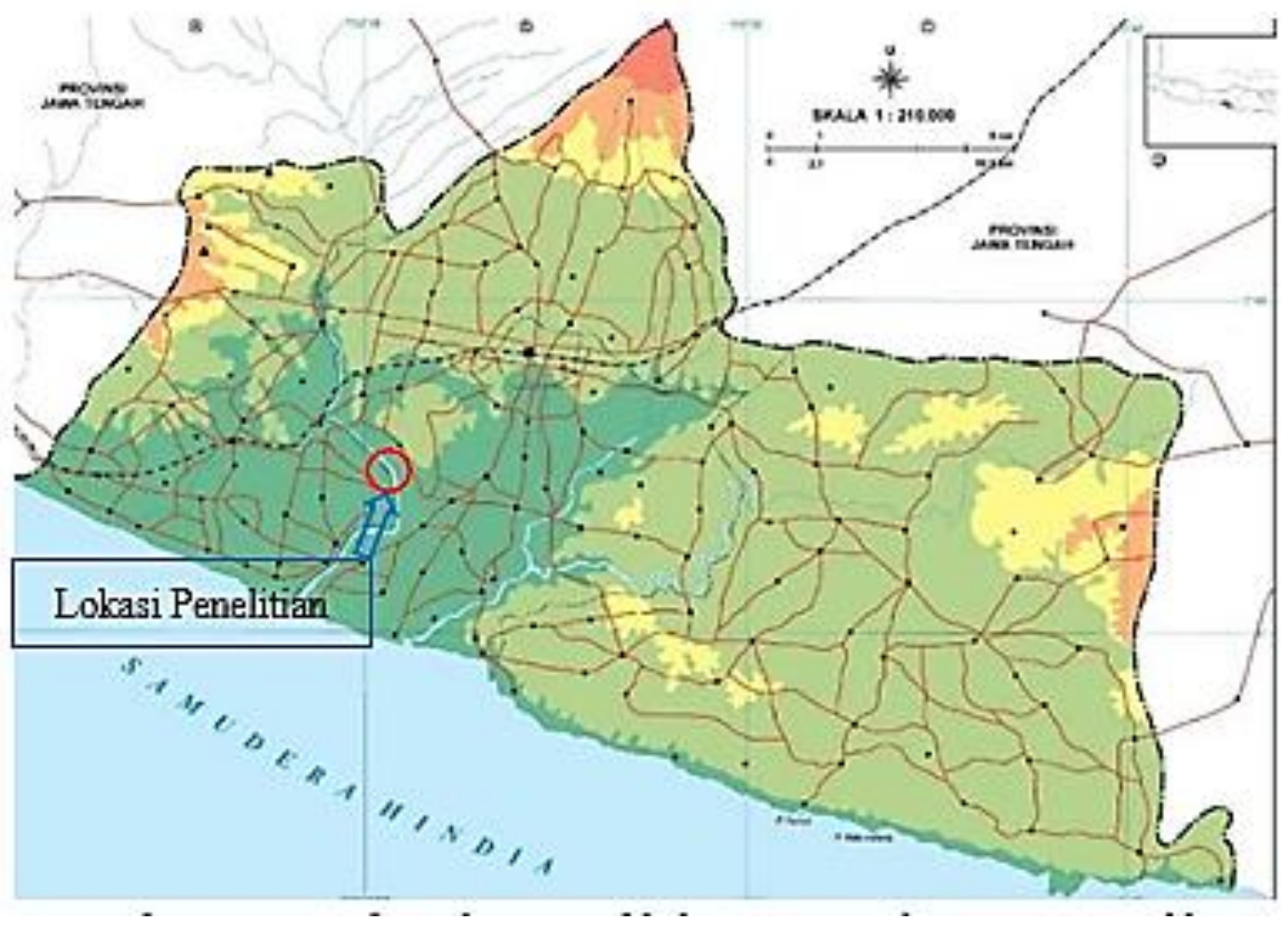

Gambar 1 Lokasi penelitian Bendung Kamijoro 
mengalikan antara koefisien gempa dengan gaya berat tubuh bendung yang telah dihitung sebelumnya. Setelah hasil gaya gempa telah diketahui maka dapat dilakukan perhitungan momen gempa dengan lengan momen.

\subsection{Analisis Gaya $U$ plift}

Gaya uplift dianalisis dengan menggunakan metode jaringan aliran (flow net). Dalam penggambaran jaringan aliran, garis-garis aliran dan ekipotensial haruslah tegak lurus satu sama lain, sehingga elemen-elemen aliran yang dibuat dapat mendekati bujur sangkar. Penggambaran jaringan aliran di bawah tubuh bendung Kamijoro ditunjukkan pada Lampiran Gambar A.2. Debit rembesan pada flow net berdasarkan Hukum Darcy. Debit aliran rembesan dapat dihitung dengan langkah-langkah berikut:

a) Selisih tinggi muka air antara hulu dengan hilir $(H)$

b) Jumlah kehilangan energi potensial $(\mathrm{Nd})$

c) Jumlah saluran aliran atau flow channels

d) Beda tinggi energy $\Delta h$, yaitu dengan persamaan 1 .

$$
\Delta h=\frac{H}{N_{d}}
$$

e) Debit total $\Delta q$, dihitung dengan menggunakan persamaan 2 .

$$
\Delta q=k \frac{H}{N_{d}}
$$

Setelah dilakukan perhitungan debit total selanjutnya dilakukan perhitungan gaya uplift dengan tinjuan beberapa titik pada tubuh bagian dasar bendung. Gaya uplift pada jaringan aliran dapat dihitung dengan langkah-langkah berikut:

a) Jumlah kehilangan energi potensial terhadap titik tinjau A (lihat Gambar 2).

b) Beda tinggi energi titik $\mathrm{A}$

$$
H_{A}=H_{1}-\left(N_{d(A)} \times \Delta h\right)
$$

dengan $H_{A}$ adalah beda tinggi pada titik $A(m)$ dan NDA adalah jumlah head drops titik A

c) Gaya uplift titik A

$$
U_{A}=\rho_{w} \times\left(H_{A}-z_{A}\right)
$$

dengan $U_{A}$ adalah gaya uplift pada titik $\mathrm{A}\left(\mathrm{t} / \mathrm{m}^{2}\right), \rho_{w}$ adalah rapat massa air $\left(\mathrm{t} / \mathrm{m}^{3}\right)$, dan $\left(H_{A}-z_{A}\right)$ adalah tinggi energi titik A dikurangi tinggi titik A dari tanah dasar (m).

d) Momen uplift titik A

$$
M_{A}=U_{A} x
$$

Dimana $M_{A}$ adalah momen pada titk A (Tm).

\subsection{Analisis Gaya Berat Air}

Gaya berat air pada bagian atas bendung terdiri dari gaya horizontal dan gaya vertikal sebagaimana ditunjukkan pada Gambar 3. Berdasarkan Gambar 3, gaya berat air dihitung dengan persamaan 6 .

$$
W_{h}=0,5 \times a \times z \times l \times \rho_{w}
$$

dimana Wh adalah gaya berat air (ton), $a, z$, dan $l$ menunjukkan volume yang ditinjau.

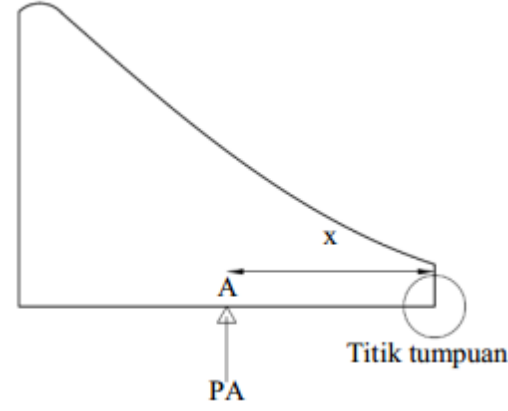

Gambar 2 Gaya berat air pada tubuh bendung

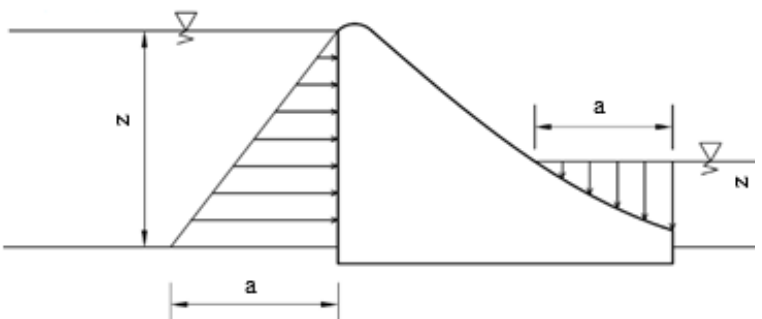

Gambar 3 Gaya berat air pada tubuh bendung

Setelah gaya berat diketahui, kemudian dilakukan penghitungan momen dengan lengan momen adalah jarak pusat gaya terhadap titik tumpuan.

\subsection{Analisis Gaya Tekan Lumpur}

Gaya tekan lumpur pada bendung diakibatkan karena adanya kumpulan lumpur yang mengendap pada permukaan bendung. Kumpulan lumpur tersebut dibawa oleh aliran air akibat dari erosi dasar sungai maupun hanyutan sedimen-sedimen yang berasal dari gunung. Gaya tekan lumpur terhadap sisi hulu bangunandapat dihitung dengan dengan persamaan 7 .

$$
P_{S}=\frac{\rho_{S} h^{2}}{2}\left(\frac{1-\sin \phi}{1+\sin \phi}\right)
$$

dengan $P_{S}$ adalah gaya tekan lumpur (ton/m), $\rho_{s}$ adalah rapat massa lumpur (ton $/ \mathrm{m}^{3}$ ), h adalah kedalamanlumpur (m), dan $\phi$ adalah sudut gesekan dalam.

Setelah gaya tekan diketahui, dapat dilakukan perhitungan momen yaitu dengan mengalikan gaya tekan lumpur (Wh) dengan lengan momen $(y)$.

\subsection{Analisis Reaksi Pondasi}

Reaksi pada suatu pondasi diakibatkan oleh gaya-gaya vertikal baik dari tubuh bendung itu sendiri maupun gayagaya eksternal lainnya, sehingga menyebabkan pondasi bereaksi dengan menahan gaya-gaya tersebut dan meneruskannya ke tanah. Perhitungan reaksi pondasi dapat dilakukan dengan menggunakan persamaan 8 .

$$
P=\frac{\sum W_{V}}{A}+\frac{\sum W_{V} e}{I} m
$$

dengan $P$ adalah tekanan vertikal pondasi (ton), $W_{V}$ adalah gaya vertikal (ton), A adalah luas dasar $\left(\mathrm{m}^{2}\right)$, e adalah eksentrisitas pembebanan $(\mathrm{m})$, I adalah momen kelembaman dasar $\left(\mathrm{t} . \mathrm{m}^{2}\right)$ dan $m$ adalah jarak dari titik 
pusat luas dasar sampai ke titik dimana tekanan dikehendaki.

\subsection{Stabilitas Terhadap Gelincir}

Kontrol stabilitas terhadap gelincir, dilakukan menggunakan persamaan 9 .

$$
\frac{\sum W_{H}}{\sum\left(W_{V}-U\right)}=\tan \theta<\frac{f}{S_{1}}
$$

dimana $W_{H}$ adalah gaya horizontal (ton), $\theta$ adalah sudut resultan semua gaya terhadap garis vertical, $f$ adalah koefisien gesekan (berdasarkan pada Tabel 1) dan $S_{1}$ adalah faktor aman terhadap gelincir (2 untuk kondisi normal dan 1,25 untuk kondisi ekstrim).

\subsection{Stabilitas Terhadap Guling}

Kontrol stabilitas terhadap guling dapat dihitung dengan persamaan berikut (Direktorat Jenderal Sumber Daya Air, 2013).

$$
d x \geq S_{2} \frac{U x-H x}{\tau}
$$

Diman $d x$ adalah tebal lantai pada titik $x, U x$ adalah gaya angkat pada titik $x\left(\mathrm{t} / \mathrm{m}^{2}\right), H \mathrm{x}$ adalah kedalaman air dari titik $x(\mathrm{~m}), \tau$ adalah massa jenis bahan $\left(\mathrm{t} / \mathrm{m}^{3}\right), \mathrm{S}_{2}$ adalah faktor aman terhadap guling (1,5 untuk kondisi normal dan 1,25 untuk kondisi ekstrem).

\subsection{Stabilitas Terhadap Pipping}

Kontrol stabilitas terhadap pipping dilakukan dengan persamaan 11 .

$$
C_{L}=\frac{\sum L_{p}+1 / 3 \sum L_{H}}{H}
$$

dimana $C_{L}$ adalah angka rembesan Lane, $L_{P}$ adalah panjang vertikal $(\mathrm{m}) ; L_{H}$ adalah panjang horizontal $(\mathrm{m})$, dan $H$ adalah beda tinggi muka air (m).

Tabel 1 Harga perkiraan koefisien gesekan (Direktorat Jenderal Sumber Daya Air, 2013)

\begin{tabular}{ll}
\hline Bahan & $f$ \\
\hline Pasangan batu pada pasangan batu & $0,60-0,75$ \\
Batu keras berkualitas baik & 0,75 \\
Kerikil & 0,50 \\
Pasir & 0,40 \\
Lempung & 0,30 \\
\hline
\end{tabular}

Tabel 2 Harga Minimum Rembesan Lane (Direktorat Jenderal Sumber Daya Air, 2013)

\begin{tabular}{lcc}
\hline Material & \multicolumn{2}{c}{ Rembesan C } \\
\cline { 2 - 3 } & Lane & Blight \\
\hline Pasir sangat halus atau lanau & 8,5 & 18 \\
Pasir halus & 7,0 & 15 \\
Pasir sedang & 6,0 & - \\
Pasir kasar & 5,0 & 12 \\
Kerikil halus & 4,0 & - \\
Kerikil sedang & 3,5 & - \\
Kerikil kasar termasuk berangkal & 3,0 & 9 \\
campur pasir & & \\
Bongkah dengan sedikit berangkal dan & 2,5 & $4-6$ \\
kerikil & 3,0 & - \\
Lempung lunak & 2,0 & - \\
Lempung sedang & 1,8 & - \\
Lempung keras & 1,6 & - \\
Lempung sangat keras & &
\end{tabular}

Setelah dilakukan perhitungan menggunakan persamaan 1 hingga 11, maka selanjutnya dilakukan evaluasi terhadap angka rembesan guna menentukan kondisi keamanan bendung seusai ketentuan harga minimum Lane pada Tabel 2.

\section{HASIL DAN PEMBAHASAN}

\subsection{Gaya Berat Bangunan}

Perhitungan gaya berat bangunan Bendung Kamijoro dilakukan dengan pembagian setiap pias bangunan. Berdasarkan dari hasil perhitungan gaya berat tubuh bendung seperti ditampilkan pada Tabel 3, diketahui nilai gaya berat bendung yaitu sebesar $-313,710$ ton, dengan total momen sebesar-8569,618. Momen gaya memiliki arah yang berlawanan dengan arah jarum jam, sehingga dapat diasumsikan nilai dari gaya maupun momennya bernilai negatif.

\subsection{Gava Gempa}

Percepatan gempa pada lokasi Bendung Kamijoro memiliki koefisien gempa (Kh) sebesar 0,05-0,1 untuk periode 10 tahun dengan probabilitas 20\%, pada penelitian ini diambil percepatan gempa sebesar 0.1 . Tabel 3 menunjukkan hasil perhitungan gaya gempa. Total gaya gempa yang didapatkan dari analisis perhitungan adalah 31,37 ton dan momen gempa sebesar $70,6 \mathrm{tm}$

\subsection{Gaya $U$ plift Air}

Gaya uplift pada bendung ini memiliki arah vertikal keatas melawan gaya berat tubuh bendung. Perhitungan gaya uplift, dilakukan dengan cara penggambaran jaringan aliran (flow net) seperti yang terlihat pada lampiran Gambar A.2, dan berikut diberikan hasil perhitungan gaya uplift air pada Tabel 4. Berdasarkan dari hasil perhitungan gaya uplift, diketahui bahwa nilai total gaya uplift adalah sebesar 195,16 ton dengan momen sebesar 5318,78 tm. Momen gaya memiliki arah yang sama dengan arah jarum jam, sehingga diasumsikan bernilai positif.

\subsection{Gaya Berat Air}

Pembagian elemen air pada bendung dapat dilihat pada lampiran Gambar A.3. Berdasarkan pada Gambar A.3, berikut diberikan hasil perhitungan gaya berat air Bendung Kamijoro pada Tabel 5. Dari hasil perhitungan, diketahui bahwa gaya berat air vertikal total adalah sebesar 387,221 ton dengan momen sebesar $-8057,14 \mathrm{tm}$.

\subsection{Gaya Tekan Lumpur}

Gaya tekan lumpur mengakibatkan suatu gaya tekan horizontal maupun vertikal pada tubuh bendung, yang mana gaya tersebut diberikan pada lampiran Gambar A.4, berikut diberikan hasil perhitungan gaya tekan lumpur Bendung Kamijoro pada Tabel 6. Berdasarkan dari hasil perhitungan gaya tekan lumpur pada Tabel 6, massa jenis lumpur diambil nilai sebesar $1,86\left(\mathrm{t} / \mathrm{m}^{3}\right)$ dengan sudut geseknya sebesar $30^{\circ}$, hal ini didasarkan pada hasil pengujian tanah di sekitar bendung sehingga dapat diketahui bahwa nilai total gaya tekan lumpur vertikal dan 
Tabel 3. Hasil perhitungan gaya berat bangunan dan gaya gempa

\begin{tabular}{|c|c|c|c|c|c|c|}
\hline \multirow[b]{2}{*}{ Pias } & \multicolumn{3}{|c|}{ Gravitasi } & \multicolumn{3}{|c|}{ Gempa } \\
\hline & $\begin{array}{l}\text { Gaya Berat, } W \\
\text { (Ton) }\end{array}$ & Lengan, $x(\mathrm{~m})$ & Momen (Tm) & $\begin{array}{l}\text { Gaya Gempa } \\
\text { (Ton) }\end{array}$ & $\begin{array}{c}\text { Lengan, } \\
y(\mathrm{~m})\end{array}$ & Momen (Tm) \\
\hline GI & $-2,45$ & 51,45 & $-126,053$ & 0,2 & 3,830 & 0,938 \\
\hline GII & $-2,7$ & 50,85 & $-137,295$ & 0,3 & 3,250 & 0,878 \\
\hline GIII & $-6,66$ & 48,3 & $-321,678$ & 0,7 & 4,250 & 2,831 \\
\hline GIV & $-0,6$ & 48,1 & $-28,860$ & 0,1 & 3,750 & 0,225 \\
\hline GV & $-3,75$ & 45,97 & $-172,388$ & 0,4 & 3,000 & 1,125 \\
\hline GVI & $-1,83$ & 46,57 & $-85,223$ & 0,2 & 4,910 & 0,899 \\
\hline GVII & $-2,06$ & 45,63 & $-93,998$ & 0,2 & 5,230 & 1,077 \\
\hline GVIII & $-2,43$ & 44,61 & $-108,402$ & 0,2 & 5,050 & 1,227 \\
\hline G1 & $-6,9$ & 43,5 & $-300,150$ & 0,7 & 5,240 & 3,616 \\
\hline G2 & $-12,1$ & 41,65 & $-503,965$ & 1,2 & 5,610 & 6,788 \\
\hline G3 & $-5,5$ & 39,97 & $-219,835$ & 0,6 & 5,130 & 2,822 \\
\hline G4 & $-14,04$ & 44,57 & $-625,763$ & 1,4 & 3,000 & 4,212 \\
\hline G5 & $-4,13$ & 43,15 & $-178,210$ & 0,4 & 3,500 & 1,446 \\
\hline G6 & $-1,08$ & 43,3 & $-46,764$ & 0,1 & 2,170 & 0,234 \\
\hline G7 & $-10,08$ & 41,65 & $-419,832$ & 1,0 & 3,500 & 3,528 \\
\hline G8 & $-5,76$ & 40 & $-230,400$ & 0,6 & 3,500 & 2,016 \\
\hline G9 & $-2,88$ & 39,8 & $-114,624$ & 0,3 & 1,830 & 0,527 \\
\hline G10 & $-14,4$ & 38,65 & $-556,560$ & 1,4 & 2,500 & 3,600 \\
\hline G11 & $-0,62$ & 37,6 & $-23,312$ & 0,1 & 3,190 & 0,198 \\
\hline G12 & $-5,81$ & 37,45 & $-217,585$ & 0,6 & 1,840 & 1,069 \\
\hline G13 & $-2,16$ & 37,3 & $-80,568$ & 0,2 & $-0,170$ & $-0,037$ \\
\hline G14 & $-1,71$ & 36,3 & $-62,073$ & 0,2 & 2,720 & 0,465 \\
\hline G15 & $-20,16$ & 35,95 & $-724,752$ & 2,0 & 0,840 & 1,693 \\
\hline G16 & $-39,6$ & 23,9 & $-946,440$ & 4,0 & 0,670 & 2,653 \\
\hline G17 & $-121,5$ & 18,4 & $-2235,600$ & 12,2 & 1,750 & 21,263 \\
\hline G18 & $-2,1$ & 1,73 & $-3,633$ & 0,2 & 3,080 & 0,647 \\
\hline G19 & $-0,9$ & 1,4 & $-1,260$ & 0,1 & 0,670 & 0,060 \\
\hline G20 & $-6,9$ & 0,58 & $-4,002$ & 0,7 & 1,250 & 0,863 \\
\hline G21 & $-5,88$ & 0,7 & $-4,116$ & 0,6 & 3,380 & 1,987 \\
\hline G22 & $-7,02$ & $-0,53$ & 3,721 & 0,7 & 2,500 & 1,755 \\
\hline Jumlah & $-313,710$ & & $-8569,618$ & 31,371 & & 70,604 \\
\hline
\end{tabular}

horizontal adalah sebesar -0,93 ton dan 0,91 ton dengan momennya sebesar $-42,46 \mathrm{tm}$ dan $4,86 \mathrm{tm}$.

\subsection{Reaksi Fondasi}

Perhitungan reaksi pondasi dapat dikakukan dengan cara membagi total gaya vertikal keseluruhan pada bendung dengan luasan tiap titik pondasi, yang mana titik pondasi diberikan pada lampiran Gambar A.5. Berikut diberikan hasil perhitungan total gaya vertikal pada bendung dan luasan tampang tiap titik pondasi pada Tabel 7 dan Tabel 8. Dengan menggunakan persamaan 8, diperoleh nilai reaksi setiap titik pondasi sebesar 11,05 $\mathrm{t} / \mathrm{m}^{2}$.

\subsection{Stabilitas terhadap Gelincir}

Stabilitas bendung terhadap gelincir dapat diketahui jika koefisien gesekan diperkirakan 0,40 untuk jenis pasir (lihat Tabel 1) dan nilai faktor aman diambil 2,0 yaitu untuk kondisi pembebanan normal. Menggunakan persamaan 9, didapatkan nilai 0,14 (<faktor aman) sehingga Bendung Kamijoro dapat dikatakan aman terhadap gelincir.

\subsection{Stabilitas terhadap Guling}

Tinjauan terhadap guling diambil di dua titik lantai kolam olak, yaitu titik M dan Q (lihat lampiran Gambar A.2). Berdasarkan Tabel, untuk hasil perhitungan gaya uplift telah diketahui nilai gaya uplift untuk titik $\mathrm{M}$ dan $\mathrm{Q}$ adalah sebesar $10,2 \mathrm{t} / \mathrm{m}^{2}$ dan $9,34 \mathrm{t} / \mathrm{m}^{2}$, dengan kedalaman air pada hilir sebesar $8,18 \mathrm{~m}$. Selain itu, tebal lantai beton pada titik tersebut adalah sebesar 2,3 $\mathrm{m}$ dan 1,69 m. Perhitungan dilakukan dengan kondisi pembebanan normal dengan faktor aman 1,5. 
Tabel 4 Hasil perhitungan gaya uplift pada bendung

\begin{tabular}{|c|c|c|c|c|c|c|c|}
\hline \multirow[t]{2}{*}{ Point } & \multirow{2}{*}{$\begin{array}{l}\text { Head Drops } \\
N_{d}\end{array}$} & \multicolumn{2}{|c|}{ Tinggi Point (m) Beda Tinggi (m) } & \multirow{2}{*}{$\begin{array}{l}\text { gaya } \\
\text { (ton } / \mathrm{m}^{2} \text { ) } \\
P\end{array}$} & \multirow{2}{*}{$\begin{array}{c}\text { tekanBerat (ton) } \\
U\end{array}$} & \multirow{2}{*}{$\begin{array}{l}\text { Lengan }(\mathrm{m}) \\
x\end{array}$} & \multirow[t]{2}{*}{ Momen $(\mathrm{Tm})$} \\
\hline & & $z$ & $H$ & & & & \\
\hline$\overline{\mathrm{A}}$ & 1 & 7,12 & 15,32 & 8,20 & 8,20 & 51,10 & 419,24 \\
\hline B & 6 & 7,13 & 15,30 & 8,17 & 8,17 & 50,60 & 413,24 \\
\hline $\mathrm{C}$ & 7 & 8,54 & 15,29 & 6,75 & 6,75 & 50,37 & 340,06 \\
\hline $\mathrm{D}$ & 8 & 8,1 & 15,29 & 7,19 & 7,19 & 48,09 & 345,56 \\
\hline E & 9 & 6,17 & 15,28 & 9,11 & 9,11 & 44,55 & 405,86 \\
\hline $\mathrm{F}$ & 10 & 7,21 & 15,27 & 8,06 & 8,06 & 42,79 & 345,08 \\
\hline G & 11 & 7,11 & 15,27 & 8,16 & 8,16 & 40,54 & 330,77 \\
\hline $\mathrm{H}$ & 12 & 5,20 & 15,26 & 10,06 & 10,06 & 39,4 & 396,50 \\
\hline I & 13 & 5,18 & 15,26 & 10,08 & 10,08 & 37,87 & 381,65 \\
\hline $\mathrm{J}$ & 14 & 3,19 & 15,25 & 12,06 & 12,06 & 37 & 446,31 \\
\hline K & 16 & 3,19 & 15,24 & 12,05 & 12,05 & 34,9 & 420,59 \\
\hline $\mathrm{L}$ & 20 & 4,82 & 15,22 & 10,40 & 10,40 & 29,9 & 310,94 \\
\hline M & 24 & 4,93 & 15,20 & 10,27 & 10,27 & 24,95 & 256,16 \\
\hline $\mathrm{N}$ & 28 & 5,1 & 15,18 & 10,08 & 10,08 & 19,9 & 200,49 \\
\hline $\mathrm{O}$ & 32 & 5,33 & 15,15 & 9,82 & 9,82 & 14,9 & 146,36 \\
\hline $\mathrm{P}$ & 36 & 5,56 & 15,13 & 9,57 & 9,57 & 9,89 & 94,65 \\
\hline Q & 40 & 5,77 & 15,11 & 9,34 & 9,34 & 4,98 & 46,50 \\
\hline$\widehat{\mathrm{R}}$ & 42 & 5,91 & 15,10 & 9,19 & 9,19 & 1,83 & 16,81 \\
\hline S & 43 & 4,91 & 15,09 & 10,18 & 10,18 & 1,15 & 11,70 \\
\hline $\mathrm{T}$ & 44 & 4,93 & 15,09 & 10,16 & 10,16 & 0 & 0,000 \\
\hline \multirow[t]{2}{*}{$\mathrm{U}$} & 46 & 8,81 & 15,08 & 6,27 & 6,27 & $-1,56$ & $-9,77$ \\
\hline & & Jumlah & & & 195,16 & & 5318,78 \\
\hline
\end{tabular}

Tabel 5 Hasil perhitungan gaya berat air vertikal dan horizontal pada bendung

\begin{tabular}{|c|c|c|c|c|c|c|c|}
\hline Pias & $\begin{array}{l}\text { Gaya Berat Vertikal } \\
\text { (ton) }\end{array}$ & Lengan $(\mathrm{m})$ & $\begin{array}{l}\text { Momen (tm) } \\
\mathrm{x}\end{array}$ & Pias & $\begin{array}{ll}\text { Gaya } & \text { Berat } \\
\text { (ton) } & \end{array}$ & HorizontalLengan (m) & Momen (tm) \\
\hline $\mathrm{W}_{\mathrm{V}}$ & & \multicolumn{6}{|c|}{$\mathrm{W}_{\mathrm{H}}$} \\
\hline$\overline{\mathrm{WV} 1}$ & -18.81 & 45.49 & -855.76 & WH1 & 4,495 & 5,82 & 26,161 \\
\hline WV2 & -1.43 & 46.71 & -66.70 & WH2 & 29,58 & 3,18 & 94,064 \\
\hline WV3 & -19.82 & 41.16 & -815.75 & WH3 & 0,875 & 3,43 & 3,001 \\
\hline WV4 & -0.78 & 43.06 & -33.93 & & & & \\
\hline WV5 & -3.20 & 39.70 & -127.00 & & & & \\
\hline WV6 & -15.25 & 37.45 & -571.11 & & & & \\
\hline WV7 & -268.77 & 15.30 & -4112.24 & & & & \\
\hline WV8 & -59.15 & 24.93 & -1474.61 & & & & \\
\hline$\overline{\text { Jumlah }}$ & $-387,22$ & & $-8057,15$ & Jumlah & 34,95 & & 123,227 \\
\hline
\end{tabular}

Tabel 6. Hasil perhitungan gaya tekan lumpur pada bendung

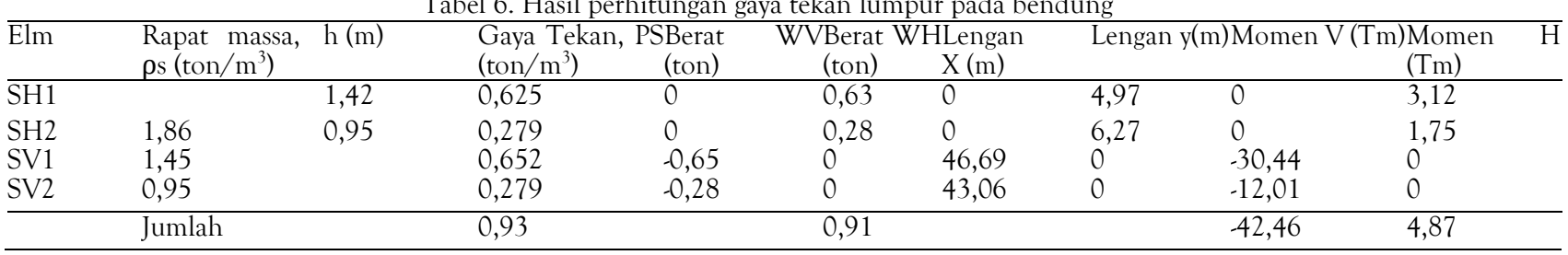

Menggunakan Persamaan 10, diketahui bahwa Bendung Kamijoro dapat dikatakan aman terhadap guling.

\subsection{Stabilitas terhadap Pipping}

Pengecekan terhadap pipping dilakukan dengan menggunakan Metode Lane. Pengecekan terhadap pipping ini dilakukan pada 2 kondisi yaitu pada muka air normal dan banjir. Tabel 9 menunjukkan data perhitungan angka aman rembesan $\left(C_{L}\right)$ pada tanah dibawah bendung. Dengan menggunakan persamaan 11 , diperoleh nilai $C_{L}$ pada kondisi banjir dan normal secara berturut-turut adalah 134,13 dan 7,93 .
Berdasarkan hasil perhitungan angka aman rembesan Lane dan ketentuan harga minimum rembesan Lane untuk jenis tanah pasir kasar (lihat Tabel 2), dapat disimpulkan bahwa lapisan tanah dibawah bendung aman terhadap pipping pada kondisi banjir maupun pada kondisi muka air normal. Karena persyaratan aman terhadap pipping untuk jenis pasir kasar hanyalah sebesar 5,0. Besar atau tidaknya nilai angka rembesan lane ini bergantung pada nilai dari selisih antara tinggi muka air hulu dan hilir, karena rembesan terjadi apabila terdapat perbedaan tinggi muka air hulu dengan hilir yang cukup signifikan. Berdasarkan hasil perhitungan diatas nilai dari angka aman rembesan lane pada kondisi banjir sangat 
Tabel 7 Hasil perhitungan total gaya vertikal pada bendung

\begin{tabular}{lc}
\hline Komponen Gaya & Gaya Vertikal \\
\hline Berat sendiri & $-313,71$ \\
Gaya gempa & 0,000 \\
Gaya air permukaan & $-387,22$ \\
Gaya air uplift & 195,16 \\
Gaya tekan lumpur & $-0,93$ \\
\hline Jumlah & $-506,69$ \\
\hline
\end{tabular}

Tabel 8 Hasil perhitungan luasan tampang tiap titik pondasi

\begin{tabular}{|c|c|c|c|}
\hline Pondasi & $\begin{array}{l}\text { Panjang } \\
(\mathrm{m})\end{array}$ & $\begin{array}{l}\text { Lebar } \\
(\mathrm{m})\end{array}$ & Luas $\left(\mathrm{m}^{2}\right)$ \\
\hline$\overline{\mathrm{A}}$ & 0,5 & & 0,5 \\
\hline B & 2 & & 2,0 \\
\hline C & 0,5 & & 0,5 \\
\hline $\mathrm{D}$ & 1,05 & & 1,1 \\
\hline E & 1,95 & 1 & 2,0 \\
\hline $\mathrm{F}$ & 2,1 & & 2,1 \\
\hline G & 1,5 & & 1,5 \\
\hline $\mathrm{H}$ & 2,1 & & 2,1 \\
\hline I & 33,02 & & 33,0 \\
\hline $\mathrm{J}$ & 1,15 & & 1,2 \\
\hline Jumlah & & & 45,9 \\
\hline
\end{tabular}

Tabel 9 Data perhitungan angka rembesan Lane

\begin{tabular}{lllll}
\hline \multirow{2}{*}{$\begin{array}{l}\text { Kondisi } \\
\text { Ver. }\end{array}$} & \multicolumn{2}{c}{ Panjang } & \multicolumn{3}{c}{ Pondusi } \\
\cline { 5 - 5 } \cline { 4 - 5 } Tinggi muka air $(\mathrm{m})$ & Hor. & & Hulu & Hilir \\
\hline Banjir & 19,49 & 46,15 & $(+28,54)$ & $(+28,28)$ \\
Normal & 19,49 & 46,15 & $(+24,50)$ & $(+20,10)$ \\
\hline
\end{tabular}

tinggi yaitu sebesar 134,13. Hal ini dikarenakan perbedaan tinggi antara muka air hulu dengan hilir sangatlah kecil yaitu hanya berkisar 0,26 m.

\section{KESIMPULAN}

Berdasarkan hasil analisis stabilitas pada Bendung Kamijoro, dapat disimpulkan bahwa:

a) Berdasarkan kepada analisis yang telah dilakukan untuk kontrol stabilitas bendung terhadap gelincir, maka Bendung Kamijoro dapat dikatakan aman terhadap gelincir. Hal ini dikarenakan nilai dari tangen resultan semua gaya pada bendung memiliki nilai 0.14 , yang mana nilai ini lebih kecil dari nilai koefisien gesekan tanah dibagi oleh nilai faktor aman yaitu sebesar 0.2 .

b) Berdasarkan analisis yang telah dilakukan pada dua titik tinjauan (titik M dan titik Q) untuk kontrol stabilitas terhadap guling, maka Bendung Kamijoro dapat dikatakan aman terhadap guling. Hal ini dikarenakan dari kedua titik tersebut yaitu titik M dan titik $Q$, tebal lantai kolam olak memiliki nilai 2.3 dan 1.69 , yang mana nilai ini lebih besar dari faktor amannya yaitu 1.26 dan 0.725 .

c) Faktor aman (safety factor) terhadap pipping pada Bendung Kamijoro ini adalah sebesar $\mathrm{C}=134.13$ (untuk kondisi banjir) dan $\mathrm{C}=7.93$ (untuk kondisi muka air normal), yang mana persyaratan aman terhadap pipping untuk nilai aman rembesan Lane pada jenis pasir kasar hanyalah sebesar 5,0. Maka Bendung Kamijoro ini dapat dikatakan sangat aman terhadap pipping.

\section{Daftar Pustaka}

Asl, M.S, Parvizi, M., Armin, M., Berronnes, R.F., 2015, Internal Erosion under Spillway Rested on an Embankment Dam, International Journal of Mining and Geo-Engineering, 49(2), 269-279

Aziz, L.J., Abdallah, H.M., 2017. Suitable Location of Sheet Pile Under Dam Resting on Sandy Soil with Cavity. Kufa Journal of Engineering, 9(2), 168-188.

Direktorat Jenderal Sumber Daya Air, 2013, Standar Perencanaan Irigasi, Kriteria Perencanaan Bagian Bangunan Utama KP-02, Kementerian Pekerjaan Umum Jakarta

Firnanda, A., Fauzi, M., Siswanto, 2011, Analisis Stabilitas Bendung (Studi Kasus:Bendung Tamiang), JomFTEKNIK, 3(2), 1-11.

Mangroe, V.R., Wuisan, E.M., Kawet, L., Tangkudung, H., 2013, Perencanaan Bendung untuk Daerah Irigasi Sulu, Jurnal Sipil Statik, 1(7), 533-541

Prasasti, I., Suprapto, M., Surjandari, N.S., 2013, Evaluasi Hidrolis Kerusakan dan Konsep Perbaikan Bendung Cileumeuhdi Kabupaten Cilacap, Jurnal Teknik Sipil, 1(1), 54-65

Prastumi, Suseno, H., Pratama, F.Y., 2011, Studi Perencanaan Bentuk Bendungan Beton Sederhana yang Paling Efisien, Rekayasa Sipil, 5(3), 130-136.

Sabihi, S., Fauzi, M., Siswanto, 2011, Analisis Perencanaan Bendung (Studi Kasus Bendung Botung), JomFTEKNIK, 4(2), 1-17

Shahrbanozadeh, M., Barani, G.A., Shojaee, S., 2015, Simulation of Flow Through Dam Foundation by Isogeometric Method, Engineering Science and Technology, an International Journal, 18, 185-193.

Sompie, O.B.A., Puntororing, C., 2014. Analisis Tegangan-Regangan, Tekanan Air Pori dan Stabilitas Model Dam Timbunan Tanah. Jurnal Ilmiah Media Engineering, 4(4), 205-214.

Sroka, Z., Walczak, Z., Wosiewicz, B., 2014, Description and Application of a Model of Seepage Under a Weir Including Mechanical Clogging, Journal of Water and Land Development, 21, 3-9.

Sukirman, 2014, Analisis Rembesan Pada Bendung Tipe Urugan Melalui Uji Hidrolik Di Laboratorium Hidro FT UNSRI, Jurnal Teknik Sipil dan Lingkungan, 2(2), 238-244.

Sofyan, Z., Frizaldi, 2017. Analisa Desain Bendung D.I Kawasan Sawah Laweh Tarusan (3.273 Ha) Kabupaten Pesisir Selatan Provinsi Sumatera Barat. Jurnal Teknik Sipil ITP, 4(1), 70-78. 
LAMPIRAN

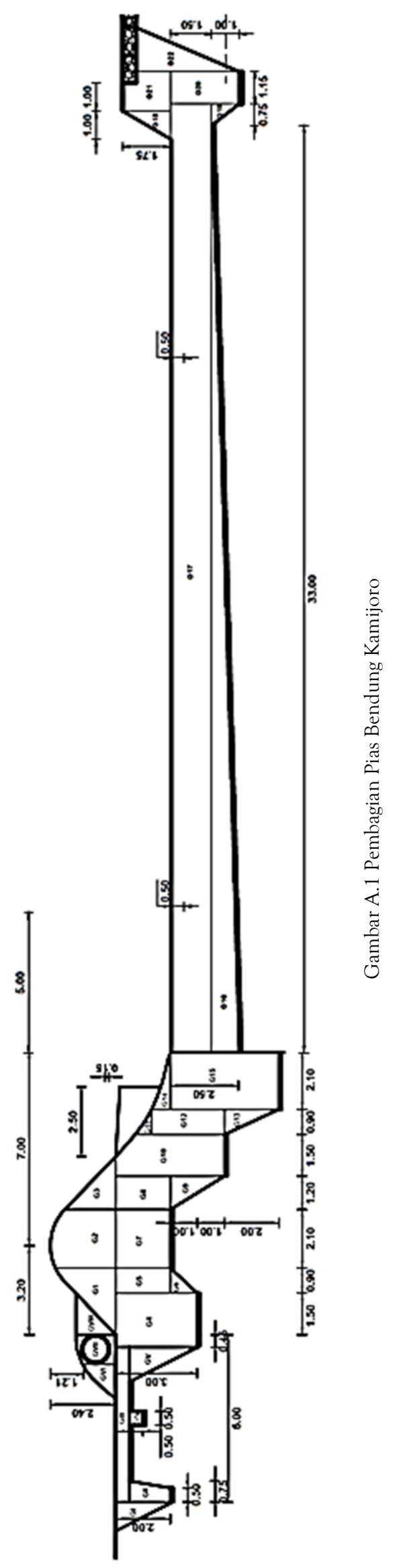




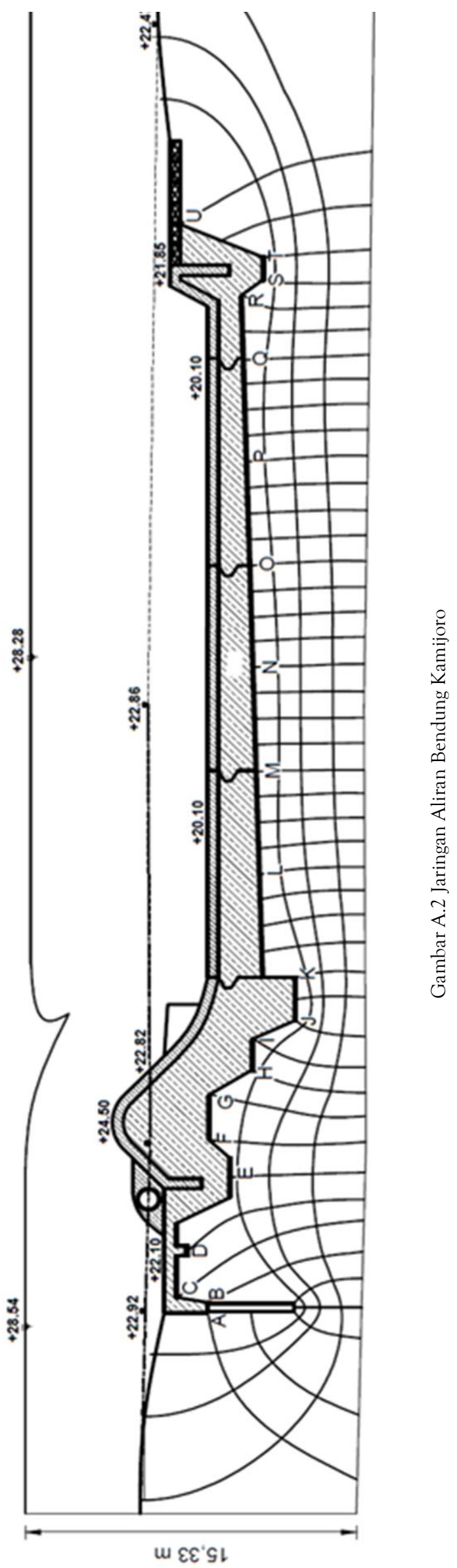




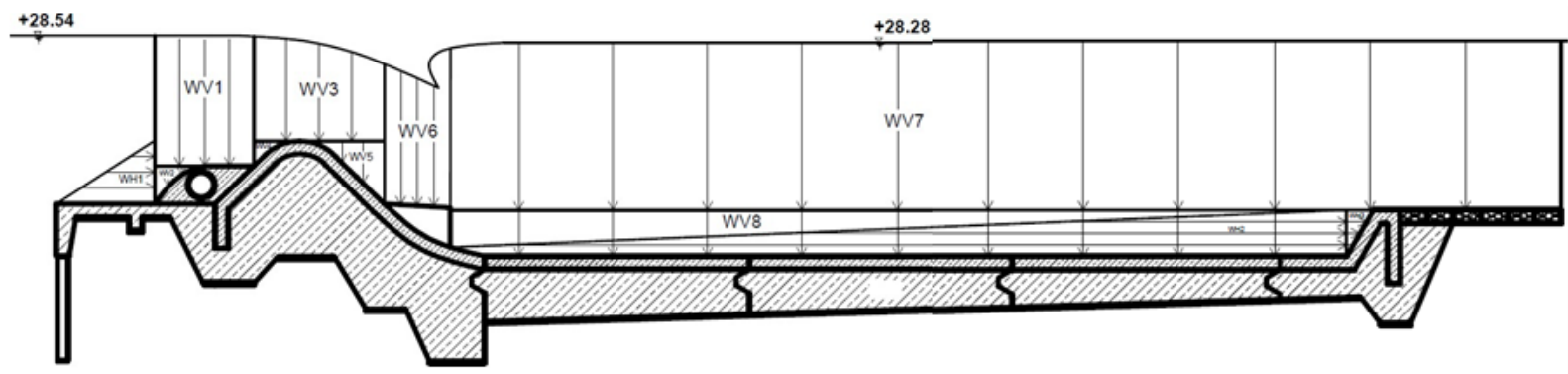

Gambar A.3 Gaya Berat Air Bendung Kamijoro

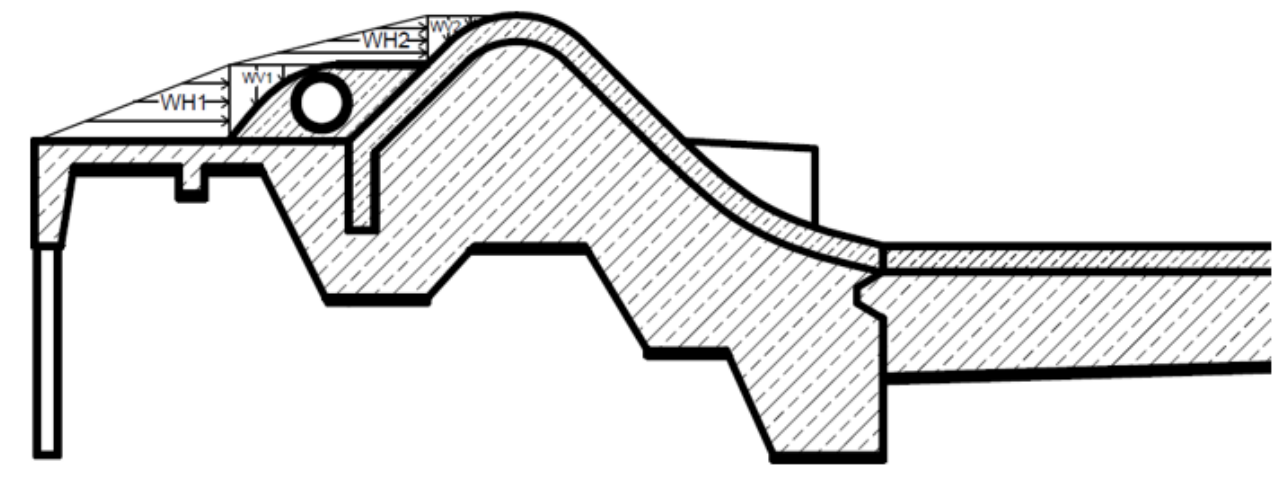

Gambar A.4 Gaya Tekan Lumpur Bendung Kamijoro

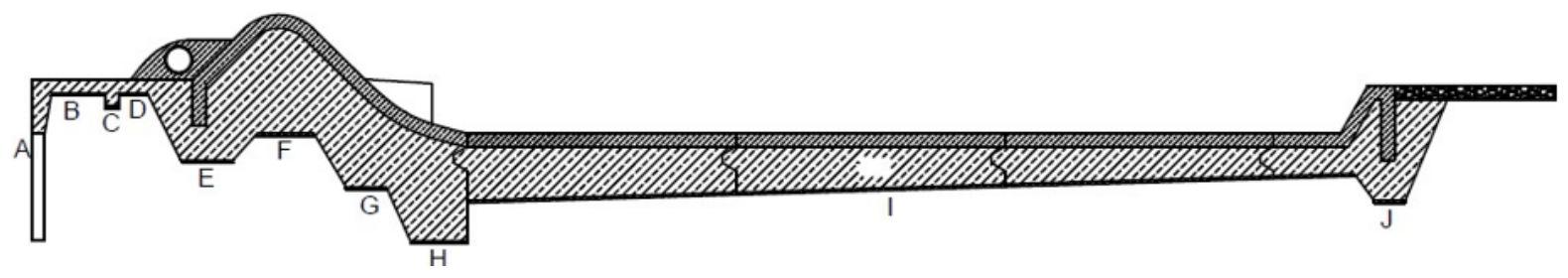

Gambar A.5 Pembagian Titik Pondasi 